\title{
Role of high quality feed supplement additional to the success of artificial insemination using sexing semen on Limousin Crossbred Cow
}

\author{
Muhammad Zainul Hanif ${ }^{1}$, Putri Utami $^{1}$, Rizki Prafitri ${ }^{2}$, Chusnul Hanim ${ }^{3}$, and Trinil \\ Susilawati ${ }^{2 *}$ \\ ${ }^{1}$ Post Graduate, Faculty of Animal Science, Universitas Brawijaya, Malang 65145, Indonesia \\ ${ }^{2}$ Faculty of Animal Science, Universitas Brawijaya, Malang 65145, Indonesia \\ ${ }^{3}$ Faculty of Animal Science, Gadjah Mada University, Yogyakarta 55281, Indonesia
}

\begin{abstract}
The success of artificial insemination must be supported by a balance of nutrients for livestock. AI combined with sexing produces offspring according to wishes of the breeder. This study aims to determine the increase in concentration on the success of Artificial Insemination using frozen semen sexing. This research was conducted at the people's beef cattle farm, Sumber Pucung District, Malang Regency. The limousine crosser used was 30 cows. Cattle aged 1.8 - 5 years with BCS 3-5 (score 19) Treatment T0 : The usual feed given by farmers (Control). T1: Control+HQFS. Parameters NRR-1, NRR-2, Conception Rate (CR), Pregnancy Rate (PR). The additional feeding of concentrate did not significantly affect the reproductive parameters. The results showed that at T0 the results of NRR-1 and NRR-2 were $80 \%$ and $73.33 \%$, respectively. while in $\mathrm{T} 1$ it was $73.3 \%$ and $66.67 \%$. The results showed that the CR in both treatments was $26 \%$ and the results showed that the PR for T0 was $26 \%$ and for T1 was 33\%. Insufficient feed consumption for all treatments based on NRC requirement data, T0 and T1 dry matter consumption respectively 6.6 and $7.3 \mathrm{Kg} / \mathrm{head} /$ day, Protein consumption 0.36 and 0.3 $\mathrm{Kg} / \mathrm{head} /$ day and TDN consumption of 3.08 and $3.20 \mathrm{~kg} / \mathrm{head} /$ day.
\end{abstract}

\section{Introduction}

The increase in meat consumption in Indonesia continues to increase, to fulfill the needs meat in Indonesia the government must import meat from abroad to fulfill the needs in Indonesia, not only that, a program to increase the amount of livestock in Indonesia must be implemented one of which is the use of productive females with artificial insemination [1]. The artificial insemination program not only increases the livestock population but also helps breeders in obtaining superior offspring, besides that it can help breeders in determining the sex of the offspring, the technology used in determining the sex of the offspring is sexing Spermatozoa [2]. Sexing Spermatozoa is a reproductive technology by separates X and Y spermatozoa [3]. Wahyudi et al [4] sexing treatment of spermatozoa

\footnotetext{
*Corresponding author: tsusilawati@ub.ac.id
} 
resulted in a decrease in the quality of spermatozoa seen from membrane damage and decreased motility of spermatozoa. This is what makes the basis for artificial insemination using frozen double doses of semen sexing or two straws for one time AI with more and more doses inseminated will increase the number of spermatozoa so that it is expected to increase the chances of higher pregnancy success. The results of Yekti et al [5] showed that AI using double dose sexing semen had a value of $\mathrm{CR}=68.75 \%$ and the results of research by [3] have a value of $\mathrm{CR}=55.56 \%$.

High-Quality Feed Supplement (HQFS) is a high-quality concentrated supplement that is a combination of protein bypass with high energy source material in the form of total digestible nutrients (TDN) and a mixture of minerals and macro minerals to meet the nutritional needs of livestock. HQFS also contains vitamins and probiotics as well as essential oils. HQFS feed is formulated from corn grain, corn gluten meal (CGM), pollard, soy beans Meal(SBM), and wheat flour which is first processed in compact pellet form. The finished pellets were then mixed with an Agromix amplifier (Mineral mix Ca $26.45 \%, \mathrm{P}$ 0.62\%, K 0.22\%, Mg 0.26\%, Na 4.70\%, S 681.7 ppm, Fe 1,44\%, Zn 300.2 ppm, Cu 229.7 ppm, Se 0.541 ppm, and Co 7.7 ppm, vitamins A, D, E, and K, probiotics (Lactobacillus acidophilus, Enterococcus faecium, Saccharomyces cerevisiae) and essential oils processed from walnuts, olives, soybeans, lavender, eucalyptus, coconut, orange, peppermint and sesame seeds), HQFS consists of $81.9 \%$ CM, 90.3\% OM, $19.56 \% \mathrm{CP}, 10.15 \% \mathrm{CF}, 0.66 \%$ $\mathrm{CF}$ and $75 \%$ TDN Astuti et al [6]. The higher the nutritional content of the feed provided increases the success rate of artificial insemination with semen sexing so that it will produce male offspring with AI success parameters including Non-Return Rate (NRR), Conception Rate (CR), and Pregnancy Rate (PR).

\section{Materials and methods}

This research was conducted on March 15th - June 20th, 2021, The Nutritional Content Test of High-Quality Feed Supplement was carried out at the Nutrition and Animal Feed Laboratory of Brawijaya University, and the Implementation of Artificial Insemination (AI) was carried out in Senggreng District, Malang Regency, East Java. The research material used was 30 Limousin Crossing Cow, 15 cows in each treatment with The concentrated feed (HQFS) from Widodo Makmur Cianjur.

The method used in this research was the experimental method with field experiments. The sampling technique was using the Purposive Sampling method with the criteria of cow aged 1.8-5 years based on permanent incisors, normal reproduction, BCS 3-5 with a scale of 1-9, not yet AI done again after giving birth. The sample of this study used 30 Limousine crossed cows that had not been AI after giving birth, with different feeding treatments for each treatment, namely:

T0: Control

T1: Control + Concentrated Feed (HQFS)

*Control : Feed From farmers

Table 1. The result nutrition of proximate in High quality feed supplement.

\begin{tabular}{|c|c|c|c|c|c|}
\hline $\begin{array}{l}\text { Dry } \\
\text { Matter \% }\end{array}$ & $\begin{array}{l}\text { Organic } \\
\text { Matter \% }\end{array}$ & $\begin{array}{l}\text { Crude } \\
\text { Protein \% }\end{array}$ & $\begin{array}{l}\text { Crude } \\
\text { Fiber (\%) }\end{array}$ & $\begin{array}{l}\text { Extract ether } \\
(\boldsymbol{\%})\end{array}$ & TDN (\%) \\
\hline 86.63 & 93.52 & 10.99 & 10.11 & 2.00 & 61.37 \\
\hline
\end{tabular}

The stages of the research include 1) Selection of the cow as acceptors 2) feeding according to the treatment 3 ) on day 14 of treatment the feed is synchronized using PGF 2 alpha with 
the brand Lutelyse if it shows estrus, we will do AI 4) Thawing straws with tap water temperature for 30 seconds 5) AI is carried out based on observations of signs of estrus that appear in livestock and is supported by using a heat detector to ensure that cow is ready for AI. AI was carried out using frozen semen, Sexing in double doses, at the 2nd and 8th hours, semen deposition in the 4+ position (deep insemination) According to Susilawati [1] Semen deposition in the 4+ has a higher success rate of pregnancy when compared to position 4, and then injected with bio-ATP with the brand "Rheinbio" which was carried out after the AI was carried out. 6) After one cycle day $19-22$, NRR-1 is observed, if it shows signs of estrus in AI return, using the same AI method and on day $38-42$, NRR-2 is observed, then after more than 30 days, pregnancy examination is carried out using Ultrasound.

\subsection{Measurement of body weight (BW)}

Measurement of body weight of livestock using the method of estimation of body weight by measuring the chest size (CS) using the Dalton tape which is a chest size measuring device that already has an estimated body weight in kilograms. Measurement of body weight to determine the condition of the livestock body and the nutritional needs of livestock. The formula for calculating body weight estimation is as follows:

$$
\mathrm{CW}=\frac{(C S+22)^{2}}{100}
$$

Description:

CW: Cow Weight

CS: Chest Size

Periembawe et al [7]

\section{Body Condition Score (BCS):}

Observation of BCS in livestock is an indicator to determine the nutritional status of livestock. Observations were made by observing 6 observation points and doing palpation, namely at the base of the tail (Tail head), the pelvis (Rump), pelvis (Hip Bone), sitting bones (Pin Bone), spine (Back Bone) and ribs (Ribs) by categorizing thin for BCS (1-4), ideal (5-7) and fat (8-9) [8]

\section{Non-Return Rate (NRR) including NRR1 and NRR2}

The NRR value was obtained by observing the acceptors on days $18-21$ and days $40-42$ after AI was implemented. NRR is the percentage of cattle that do not show signs of estrus after AI and can be assumed to be pregnant cattle [9].

$$
\mathrm{NRR}=\frac{\text { number of } \text { AI cattle-number of returning AI cattle }}{\text { number of AI cattle }} \times 100 \%
$$

\section{Conception Rate (CR)}

Conception Rate (CR) is the percentage of pregnant cattle in AI in the first AI and is also called the conception rate [10] with the following formula: 
$\mathrm{CR}=\sqrt{\frac{\text { number of pregnant cattle }}{\text { number of Al cattle }}} \times 100 \%$

4. Pregnancy Rate

Pregnancy rate is the percentage of pregnant cow based on rectal palpation compared to the number of cow in AI [11]

Pregnancy Rate $=\sqrt{\frac{\text { number of pregnant cattle }}{\text { total of female cattle breed }}} \times 100 \%$

\subsection{Intermediate Variable:}

\section{Feed Intake}

The feed used by breeders as acceptors is weighed in the morning and evening and weighing the rest of the provision in the morning before giving in the morning by the breeder, weighing the provision and the rest of the feed aims to determine the amount of feed consumption in livestock for 1 day in acceptor livestock.

$\sum$ Feed Consumption $=\sum$ Feeding $-\sum$ Letover Feed

Dry Matter Intake(DM)

Calculation of crude materials consumption with the following formula:

Dry Matter Intake $=\frac{\text { dry matter }}{100} \mathrm{x}$ feed consumption

Calculating protein consumption by means of the percentage of protein content multiplied by the consumption of the $\mathrm{CM}$ feed, with the following formula:

Crude protein consumption $=\frac{\text { crude protein }}{100} \times$ Dry matter consumption

Periembawe et al [7]

Data obtained from the results of research on the success of AI include No-Return Rate (NRR), Pregnancy Rate, Conception Rate (CR), DM, CP, And TDN consumtion analyzed using descriptive, Acceptor performance research includes body weight (BW), Body Condition Score (BCS) was analyzed using T-test.

\section{Results and discussion}

\subsection{Cow performance}

Table 2. Cow performance

\begin{tabular}{|c|c|c|}
\hline Treatment & Average BCS & Body weight \\
\hline T0 & $3.87 \pm 0.83$ & $324.20 \pm 33.91$ \\
\hline
\end{tabular}




\begin{tabular}{|l|l|l|}
\hline T1 & $3.67 \pm 0.62$ & $341.00 \pm 53.93$ \\
\hline
\end{tabular}

In this research, each treatment consisted of 15 cows, based on table 2 . in treatment T0 and $\mathrm{T} 1 \mathrm{had}$ an average $\mathrm{BCS}=3.87 \pm 0.83$ and $3.67 \pm 0.62$, there was no significant difference $(P>0.05)$. While treatments T0 and T1 had a bodyweight of $324.20 \pm 33.91 \mathrm{Kg}$ and 341.00 $\pm 53.93 \mathrm{Kg}$. Between treatments, no significant difference was shown $(P>0.05)$

Body Condition Score (BCS) in a cow is closely related to nutritional adequacy status in livestock and will affect the condition of the reproductive organs according to Michael et al. [12] The BCS of a cow during childbirth is an important factor to determine the timing of estrus again after further calving. Sarah et al.[13] cows with a BCS of $4-6$ have a better pregnancy rate than those with a lower BCS, This is related to the adequacy of nutrition in cows to produce hormones, reproduction, and meet the production needs of livestock.

Bodyweight in livestock is crucial to note because it illustrates the contribution of the quantity and quality of feed consumed by the cow, according to Sarah et al. [14] the increase in body weight has a relationship with livestock fertility, bodyweight at the beginning of the mating period immensely affects physiological and anatomical development of the reproductive organs to achieve reproductive success in livestock.

\subsection{Feed Intake}

Based on the average dry matter consumption at T0 and T1 were 6.6 and $7.3 \mathrm{~kg} / \mathrm{head} /$ day, while the dry materials requirements based on NRC were 8.0 and $8.5 \mathrm{~kg} / \mathrm{head} / \mathrm{day}$. Based on these data, it shows that the average dry materials consumed are lower or insufficient than they need based on the NRC at T0 and T1. The condition of insufficient dry ingredients consumed by livestock is influenced by one of them by the condition of feed that is around the research location which is mostly only straw.Survival of livestock, especially in the provision of quality forage for livestock. Hersom et al.[15] said that dry ingredients consumption in livestock is influenced by cow body weight, the quality of available forage (energy and protein concentration), and BCS, a cow with large BCS and body weight have the potential to consume greater forage than a cow with low body weight.

Based on the average crude protein consumption at T0 and $\mathrm{T} 1$ were 0.36 and 0.3 $\mathrm{kg} / \mathrm{head} /$ day, while the crude protein requirements based on NRC were 0.89 and 0.9 $\mathrm{kg} / \mathrm{head} /$ day. Based on these data, it shows that the average crude protein consumed is lower or insufficient than they need based on the NRC at T0 and T1. This is conveyed by Funston [16] that the intake of livestock feed will decrease when the content of feed consumed is low, the intake of forage will lower which is related to decreased microbial activity in the rumen, whereas if the crude protein is high, the intake of forage consumed will be higher. Funston [17] stated that excessive and deficient feeding has an impact on livestock reproduction if overfeeding leads to low pregnancy success and protein deficiency leads to weak estrus, low conception, and premature birth.

Based on the average consumption of Total Digestible Nutrient at T0 and T1 were 3.08 and $3.20 \mathrm{~kg} / \mathrm{head} / \mathrm{day}$, while the need for Total Digestible Nutrient based on NRC were 5.2 and $5.5 \mathrm{~kg} / \mathrm{head} /$ day. Based on these data, it shows that the average Total Digestible Nutrient consumed is lower or insufficient than they need based on the NRC at T0 and T1. According to Indah et al. [18], the TDN content will increase if the CP and CF in the feed ratio increase, according to Ayuningsih et al. [19] cows experiencing protein and energy deficiencies will have an impact on reproductive failure and loss of body weight. Lack of energy consumption can cause livestock to experience delayed ovulation according to Negussie [20] which states that livestock that experiences slow uterine involution and has low fertility rates are caused by the availability of energy in the livestock's body that is low 
or insufficient for the process of forming reproductive hormones. High energy availability is caused by high consumption of TDN by livestock so that livestock will use sufficient energy for productivity, basic life, and reproduction which will activate the LH hormone which functions for the follicle formation process [21]

\subsection{The successful pregnancy results from artificial insemination using double doses}

Table 3. Results of Observing the Success of IB Non-Return Rate 1, Non-Return Rate 2, Conception Rate (CR) and Pregnancy Rate (PR)

\begin{tabular}{|c|c|c|c|c|}
\hline Treatment & $\begin{array}{c}\text { NRR-1 total } \\
(\boldsymbol{\%})\end{array}$ & $\begin{array}{c}\text { NRR-2 total } \\
(\boldsymbol{\%})\end{array}$ & $\begin{array}{c}\text { Conception Rate } \\
\text { Head (\%) }\end{array}$ & $\begin{array}{c}\text { Pregnancy Rate } \\
\text { Head (\%) }\end{array}$ \\
\hline T0 & 80 & 73,33 & (4) 26 & (4) 26 \\
\hline $\mathrm{T} 1$ & 73,33 & 66,67 & (4) 26 & (5) 33 \\
\hline
\end{tabular}

The results NRR1 and NRR2 at T0 observations are greater than T1. Based on Table 1 above, there was a decrease in the value from NRR 1 to NRR2 in treatment T0 and T1, namely T0 decreased from $80 \%$ to $73.33 \%$ and $\mathrm{T} 1$ from 73.33 to $66.67 \%$. The decrease in the value of NRR 1 to NRR 2 may be due to the occurrence of an unknown heat by the breeder, the occurrence of silent heat (or calm heat) experienced by livestock according to Salim et al. [22] stated that the low NRR value might have been caused by lack of observations made by breeders so that breeders are late in providing information to inseminator officers for AI, in addition to that, an embryonic death can cause a decrease in the NRR value as well. Non-Return Rate (NRR) is one of the assessments of the success of AI by observing cows that are not in heat at NRR-1 19-21 days post-IB and NRR-2 39-41 post-AI according to Yus et al. [23] stating that NRR as Observations to assess the success of AI are often carried out as indicators of livestock fertility, age factors, environmental factors, and cage management affect livestock fertility.

Maintenance management is one of the provisions of feed by breeders. Providing adequate nutrition for female livestock is extremely essential in supporting the reproductive performance of female livestock. An adequate-protein consumption in female livestock will affect the performance of FSH and LH hormones which will begin to show signs of heat until pregnancy occurs according to Martin et al.[24] stated that feeding with high protein causes higher pregnancy rates compared to livestock that consumes low protein. The age factor of livestock affects the readiness of livestock reproductive organs for implantation, Saili et al. [25] the older the age, the higher chance of decrease in the ability to reproduce, in cows aged $3-4$ years have a higher NRR value of cow aged 5-6 years, namely $100 \%$ and $67 \%$.

The results of observations on the CR and PR values are very low, namely the CR T0 and $\mathrm{T} 1$ values are $26 \%$, and the $\mathrm{PR}$ values at $\mathrm{T} 0$ are $26 \%$ and $\mathrm{T} 1$ are $33 \%$, according to Ihsan et al. [26] stating that the condition of livestock in Indonesia with crosses that have Many have done and the natural conditions of Indonesia, which is a subtropical area, are said to have good CR when it reaches $45 \% 50 \%$. The low value of $\mathrm{CR}$ is influenced by many factors, one of the factors in this study is the use of sexing cement which is produced from a long process, this is conveyed by Yekti et al. [27]. In males, sexing semen has lower quality than non-sexing semen because during the sexing semen process it goes through a long series and damages spermatozoa physically and physiologically Bonneya et al. [28] the centrifugation process reduces the motility of spermatozoa and damages the acrosome and membranes. Pregnancy examination was carried out by rectal palpation and 
using ultrasonography which was carried out when 2 months of age after AI was reached, according to Szelenyi et al.[29] stated that ultrasound examination of pregnancy is better done at gestational age above 28 days this is done to facilitate identification of the fetal heart). The low pregnancy rate is also caused by AI acceptors found in underdeveloped follicles, and ovarian hypofunction, the condition of these reproductive organs is influenced by reproductive hormones, one of which is the quality of feed provided by breeders. Meteer et al. [30] Feeding inadequate quantity and quality leads to reduced hormone and reproductive function in livestock, livestock that lacks feed experienced a decrease in body weight accompanied by a decrease in glucose, resulting in the minimization release of $\mathrm{GnRH}$ from the hypothalamus leading to a reduction in LH concentration needed for ovulation and fat where both is a precursor of the hormone progesterone and estrogen that helps to maintain pregnancy as well as signs of estrus.

\section{Conclusion}

The results show that at T0 of NRR- 1 and NRR-2 are $80 \%$ and $73.33 \%$ respectively. while in $\mathrm{T} 1$ it is $73.3 \%$ and $66.67 \%$. It is proven that the CR in both treatments was $26 \%$ and the outcome of the PR for T0 is $26 \%$ and for T1 is $33 \%$. Feed consumption for all treatments is not sufficient based on NRC needs data, dry matter consumption T0 and T1 were 6.6 and $7.3 \mathrm{Kg} / \mathrm{head} / \mathrm{Day}$, protein consumption is 0.36 and $0.3 \mathrm{Kg} / \mathrm{head} /$ day and TDN consumption is 3.08 and $3.20 \mathrm{Kg} / \mathrm{head} /$ day. With the additional feed, as much as $1 \mathrm{~kg}$ of concentrate has not affected reproductive parameters exceedingly, therefore no research is needed on the provision of concentrate on the success of the pregnancy.

We thank the University of Gadjah Mada and the University of Sebelas Maret for joining the Indonesian collaborative research program (Kemenristek)

\section{References}

1. T. Susilawati, Jurnal Ternak Tropika (Journal of Tropical Animal Production), 12 (2011)

2. T. Susilawati, Sexing Spermatozoa, 2014.

3. M. T. Fernanda, T. Susilawati, N. Isnaini, Jurnal Ilmu Ilmu Peternakan (Indonesian Journal of Animal Science), 24 (2014)

4. L. Wahyudi, T. Susilawati, N. Isnaini, Jurnal Ternak Tropika (Journal of Tropical Animal Production), 15 (2014)

5. A. P. A. Yekti, E. A. Octaviani., Kuswati., T. Susilawati, Jurnal Ternak Tropika (Journal of Tropical Animal Production), 20 (2019)

6. A. Astuti, A. Agus, D. S. Priyono, S. Budhi, Buletin Peternakan, 33 (2009)

7. D. K. A. Periembawe, R. Sutrisna, Liman, Jurnal Ilmu Peternakan Terpadu, 4 (2016)

8. E. E. Dan, F. B. Milyssa, B. H. John., E. D. Richard, Virginia Coorperative Extension, (2009)

9. M. R. Jainudeen, E. S. E. Hafez, Cattle and Buffalo in Reproduction in Farm Animals ed By E. S. E. Hafez and B. Hafez, (2020)

10. H. Ayres, R. M. Ferreira, J. R. S. T. Junior, C. G. B. Demetrio, M. F. S. Fihlo, L. U. Gimenes, L. Penteado, M. J. D. Occhio, P. S. Baruselli, Theriogenology, 82 (2014)

11. D. P. Berry, R. D. Evans, S. Mc. Parland, Theriogenoloy, 75 (2011)

12. J. D. Michael, S. B. Pietro, G. Campanile, Theriogenology, 125 (2019)

13. E. D. Sarah, F. E. Michelle, K. A. Lisa, B. E. Joshua, N. W. Bailey, W. D. Paul, P. R. Soren, H. B. Fernando, Journal of Animal Science and Biotechnology, 10 (2019)

14. E. M. Sarah, H. B. Fernando, Journal of animal science and biotechnology, 11 (2020) 
15. Hersom, J. Matthew, Basic Nutrient Requirements Of Beef Cows, EDIS : 1-12 (2007)

16. Funston, Rick, The State Of Beef Conference, $\left(2014^{\mathrm{a}}\right)$

17. Funston, Rick, The AABP Proceedings, $47\left(2014^{\mathrm{b}}\right)$

18. S. A. Indah, L. G. Permana, Despal, Sains Peternakan, 18 (2020)

19. B. Ayuningsih, I. Hernaman, D. Ramdani, Siswoyo, Jurnal Ilmiah Peternakan Terpadu, $6(2018)$

20. T. Nigussie, J. Dairy Res. Tech., 1 (2018)

21. E. Mulyanti, F. K. Keraf, Jurnal Sain Peternakan Indonesia, 16 (2019)

22. A. Salim, A. P. A. Yekti, K. Kuswati, T. Susilawati, Ternak Tropika (Journal of Tropical Animal Production), 19 (2018).

23. E. Yus, F. J. Dieguez, Pesq Agropec Brasilia, 46 (2011)

24. J. L. Martin, K. A. Vonnahme, D. C. Adams, G. P. Lardy, R. N. Funston, J. animal science, 85 (2014)

25. T. Saili, L. Ode Baa, L. O. A. Sani, S. Rahadi, I. W. Sura, F. Lopulalan, Jurnal Ilmu Ternak, 16 (2016)

26. M. N. Ihsan, S. Wahjuningsih, Jurnal Ternak Tropika, 12 (2011)

27. A. P. A. Yekti, T. U. Kurniaesa, N. Isnaini, Kuswati, T. Susilawati, J. Ilmu Peternakan, 28 (2018)

28. Boneya, Galma, International Journal of Advanced Research in Biological Sciences, 8 (2021)

29. Z. Szelényi, O. Szenci, L. Kovács, Garcia-Ispierto, Animals, 11 (2021)

30. W. C. Meteer, D. W. Shike, F. C. D. Cardoso, Acta Scientiae, 43 (2015) 